\title{
The Imaginary Landscapes of Jim Crace's Continent
}

\author{
By Petr Chalupský*
}

In each of his twelve novels, Jim Crace, who likes to refer to himself as a "landscape writer", created a distinct yet recognisable imaginary landscape or cityscape, which led critics to coin the term "Craceland" to denote this idiosyncratic milieu. Through Crace's remarkable ability to both authentically and poetically render these milieux, they appear other and familiar at the same time. Moreover, he occupies these places and spaces with communities in transition, which include people who are caught on the verge of a historical shift that necessitates certain social, economic, political and cultural changes that affect all spheres of their private and public lives. Consequently, they shatter essential aspects of their identities. A crucial role in this process is assumed by the locations through which these individuals move or reside, either permanently or temporarily. Crace's debut novel, Continent (1986), comprises seven thematically linked stories that are variations of a fictitious realm, an imaginary seventh continent whose inhabitants are going through an identitarian crisis which is, symptomatically for Crace, reflected in their spatial experience. The aim of this paper is to provide a geocritical analysis of the novel and explore how it dramatises the intricate interaction between the geographic and topographic properties of landscapes and the protagonists' psyches.

Keywords: Geocriticism, Identity, Jim Crace, Landscape, Place

\section{Introduction}

Jim Crace (b.1946) has been one of the most distinctive personalities on the British literary scene for more than four decades, and his fiction has been popular with both critics and readers. Although he has received a number of prestigious awards in Britain and the United States and has been shortlisted twice for the Man Booker Prize, he is still not as internationally renowned as some of his contemporaries, particularly the other members of the strong post-WWII generation such as Ian McEwan, Salman Rushdie, Julian Barnes and Kazuo Ishiguro. Unlike these writers and many others, who in their works from the late 1970s through the 1980s and 1990s became the chief representatives of British literary postmodernism by engaging with its prototypical narrative techniques, Crace has never really espoused such self-conscious playfulness. Instead, he has professed what he calls "traditional" writing in the sense of unrestrained storytelling following the tradition of folktales, myths, legends and parables, which allows him to "lose [him]self in the realms of pure invention" (Begley 2002), yet remain firmly rooted in a conventionally conceived and structured narrative.

However, this by no means indicates that Crace is a realist writer; the principle of his writing is an indirect, sometimes almost allegorical, reflection of reality that he achieves through dislocation. As he explains: "What traditional writing does - what I do - is to dislocate the issues of the real world and place them elsewhere" (Begley 2002). It is this fanciful "elsewhere" that has become the hallmark of his writing, and each of his novels is set in a distinct geographic location in a variety of historical periods, ranging from a late Neolithic village to a modern Western city. What may be mistaken for a

*Associate Professor, Faculty of Education, Charles University, Czech Republic. 
realistic or naturalistic aspect in his stories is rather an exceptional "preciseness of observed detail" (Tew 2006: xiii), especially from the natural world ${ }^{1}$. Yet these are not purely matter-of-fact accounts as they always combine these details with a subtle figurativeness and resourceful diction that juxtapose the earthy with the subtle, thus endowing the narrative with meaningful aesthetic and symbolic dimensions. Crace's style is poetic at times "but also possessing a level of restraint and understatement that lends muscle and nuance to his prose" (Mathews 2012). Therefore, all his novels share the workings of their author's imaginative power, which sets their universally understandable human stories into "these variously obsessed landscapes and cultures" (Kermode 1998). What connects all their protagonists is that they are exposed to a major change to which they must adapt rather quickly before they are overcome by a new world order. They are part of what Begley (2002) calls "communities in transition." As a result, they find themselves in situations in which the essentials of their identity, both individual and collective, are at stake and need to be transformed or redefined.

The fact that these protagonists are undergoing a painful personal and community crisis that forces them to question and/or revise their values and relations within a changing social system makes them accessible to the reader, no matter the concrete geo-historical parameters. The places and spaces in which these stories are set do not only help to develop the plotline, evoke an atmosphere and enrich the narrative's sensual aesthetics; they also reflect and at times even determine the characters' mental and spiritual states. Crace's fictional milieu is always a unique amalgam of the imaginative, the uncanny, the familiar and the commonplace. What critics have termed "Craceland" is "a world proportioned to reality, and yet largely a system within itself" (Tew 2006: 4), which may appear other and exotic from the outside, but turns out to be recognisable and identifiable inside. In each of his novels, Crace, who likes to refer to himself as a "landscape writer" (Begley 2003), created an alternate landscape whose spatial coordinates are deeply embedded in the text's narrative and thematic framework. Crace's debut novel, Continent (1986), assumes a specific position in this regard: it structurally consists of seven stories linked thematically by the challenges facing the protagonists, often involving their own displacement, both territorial and identitarian. Through the mosaic of these stories, Crace composes an imaginary seventh continent ${ }^{2}$ whose dwellers experience various forms of crisis. Using geocriticism as a theoretical point of departure for its analysis, this paper explores the ways in which Crace links and interconnects the protagonists' psychic, emotional and spiritual worlds with the geography and topography of territories they inhabit or find themselves in and, consequently, how the seven physical and mental landscapes make up the novel's unique fictional space-time.

\footnotetext{
${ }^{1}$ Indeed, Crace likes to refer to himself as a keen amateur natural historian (cf. Lawless, bookgroup.info).

${ }^{2}$ Many reviewers have tried to situate Continent's made up places, their suggestions ranging from Latin American via postcolonial to Third World countries. Crace himself admits that the novel's location was strongly inspired by Sudan and Botswana, though it also owes much to places outside Africa (Tew 2006: 35-36).
} 


\section{After the Spatial Turn}

Throughout the second half of the $20^{\text {th }}$ century, more and more literary theory and criticism was focused on the representation of space and place, gradually gaining the significance that time and temporality had enjoyed for centuries. This focal shift, insisting that the spatial properties of the narrative should not be restricted to mere background setting, emerged from the acknowledgement that the relationship between human beings and their environment is reciprocal and highly interactive. The fact that human beings live in space-time and both of these dimensions considerably determine our existence and are equally crucial for the formation of our identity opened to theorists a fruitful field of interest that culminated in what can be called the postmodern spatial turn. Its immediate consequence, as Emmanuelle Peraldo notes, is that "time is not the main category of analysis any longer. Space is. It is now considered as a central metaphor and topos in literature, and literary criticism has seized space as a new tool and stake" (2016: 1).

As a result, a number of often interdisciplinary critical approaches investigating literary representations of space and place have been developed since the late 1970s. These enhance literary studies with findings from other fields, such as psychology, sociology, cultural anthropology, ecology and geography. Such a broad scope necessarily produces a diversity of theory-practices, as can be demonstrated by the examples of geopoetics and psychogeography. Geopoetics challenges what it sees as a "separation of human beings from the rest of the natural world" and proposes "that the various domains into which knowledge has been separated can be unified by a poetics which places the planet Earth at the centre of experience" (Scottish Centre for Geopoetics ${ }^{3}$ ). Kenneth White, the founder of the concept of geopoetics, advocates an alternative treatment of the space we inhabit to the prevailing quantitative approach, one that would attempt to restore the principles of natural philosophy towards what may be called "cosmoaesthetics". In this sense, geopoetics represents a particular fusion of poetry and geography, a higher unity of the two in which the poet discovers the nature of the explorer in themselves (White 1992: 165-176).

Geopoetic thinking forces us to revise not only our relationship with the world, but the very relationship between language and our being in this world. In doing so, it "alerts our minds to hidden dimensions that are common to human existence, independently from cultural belonging" (Hashas 2017: xii). Geopoetics is thus far more than a literary or critical school. It is an interdisciplinary field that invites all similarly- minded thinkers, poets and writers to share ideas and experience, an umbrella platform "where poetry, thought and science come together, in a climate of reciprocal inspiration" (The International Institute of Geopoetics ${ }^{4}$ ). One of the more specifically oriented approaches this platform has generated is ecocriticism, which is concerned with how written texts respond to

\footnotetext{
${ }^{3}$ Scottish Centre for Geopoetics. Retrieved from: http://www.geopoetics.org.uk/. [Accessed: 15 December 2017]

${ }^{4}$ The International Institute of Geopoetics. Retrieved from: http://institut-geopoetique.org/en/. [Accessed 15 December 2017]
} 
modern environmentalism and the most acute ecological issues. Compared to geopoetics, ecocriticism is more avowedly ideological, tying its "cultural analyses explicitly to a "green" moral and political agenda" (Garrard 2011: 3).

What psychogeography has in common with geopoetics is its critique of the dominant, mainstream Western thinking of rational and pragmatic materialism. Otherwise, they are differently motivated. Being an ultimately urban practice, psychogeography rests in the spontaneous, solitary acts of unrestricted strolling or wandering along the "off-centre" paths and terrains of the city, around marginal, forgotten and derelict areas, the "[1]andscapes of id" (Sinclair 2003: 306). It is walking with the agenda of subverting the politics and ideology of the authorities by deliberately avoiding the officially promoted routes, places and sights in favour of the exploration and mental mapping of territories and spaces unlikely to be utilised for commercial purposes and thus destined for oblivion. Psychogeography searches for experience, not knowledge, of the present through the prism of the past. This practice is fundamentally nostalgic and, in practical terms, ineffective as it does not strive to save or protect these vanishing aspects of the cityscape. Rather, it merely records their existence and impact upon the explorer's psyche through mental projections, textual discourse and visual mediation. It is also reactionary in that it deliberately undermines the commonly held ideas of modern urban progress and planning, cherishing what in most cases stand in their way. A literary psychogeographer then aims to reconstruct, though in an inevitably fragmentary and eclectic manner, the city's physical and mental topographies through "a superimposition of local and literary history, autobiographical elements and poetic preoccupations" (Coverley 2006: 12). This practitioner attempts to expose the hidden layers and lines of force of impalpable urban experience and transform them into a representation, the process of which fuses the political, the visionary and the artistic.

\section{Geocriticism}

Although geopoetics and psychogeography have been inspiring for literary studies and criticism, their actual applicability as a general method of textual analysis and interpretation is rather limited. The first is too broadly conceived and embedded in various extra-textual realities, while the latter is too narrowly focused on a specific segment of human experience. The critical theory that provides much more universal use for literary studies is geocriticism, which is a method of analysis incorporating literary theory with the study of geographic space. It explores how different recipients engage with the spaces and places that are formative for them in terms of their identity and sense of being in the world and, along with this, how their lived spatial experience is translated into textual discourse and its interpretation. Unlike geopoetics, it is primarily concerned with the interaction between physical space and its literary rendering. Unlike psychogeography, it involves all kinds of spaces that are meaningful from the perspective of their dwellers or observers. It follows the assumption that all lived spaces are, simultaneously, real and imaginary in that they exist 
both as geographic entities and their imaginary projections, and that the relationship between them, and their very nature in consequence, can best be discovered through the study of their textual representation. Geocriticism believes that it allows "us to understand "real" places by understanding their fundamental fictionality. And vice-versa, of course. We understand fictional spaces by grasping their own levels of reality as they become part of our world" (Tally 2011b: x). Therefore, it can cast some light on how we attempt to make sense of our world and our place in it through an in-depth examination of the diverse ways in which we approach and process our spatial experiences.

Developed at the beginning of the millennium by the French scholar Bertrand Westphal and formulated in his 2007 comprehensive study Geocriticism: Real and Fictional Spaces (La Géocritique: Réel, Fiction, Espace), it soon proved to be an effective instrument for looking into the convoluted relationship between human beings and the environments they occupy. Westphal's geocriticism is built on three underlying principles: spatiotemporality, which means that the critical attention to space has appropriated, or spatialised, temporal metaphors; transgressivity, which claims that contemporary space tends to be fluid as it evinces a considerable capacity for mobility; and referentiality, which shows that the relations between reality and its textual image, or between the referent and its representation, are unstable and subject to constant movement.

The first principle, spatiotemporality, refers to the fact that no analysis of space can avoid a temporal dimension, which is why the traditional linear perception of historical time has been superseded by the relative laws of spacetime. The dynamic of an uninterrupted line gave way to the dynamic of disparate points generating a profusion of forking paths and isotropic timelines that defy a clear-cut order and hierarchy. As a result, the overriding condition of such a system is that of disorder, turbulence and non-equilibrium. However, this is viewed positively, as it allows the system to accumulate new energy and evolve into a new state. Entropy is thus the most apt trope for this spatiotemporality, and it is this heterogeneous space that contains a multiplicity of complex stories since "the bifurcation point is the key to their organization" (Westphal 2011: 20).

The second principle, transgressivity, stems from the premise that each space, whatever its essential heterogeneity, is always subject to homogenising drives. These strive to impose on limits and borders, which inevitably call for their breaking and crossing in defiance of established norms. It is a space of transgression and an oscillation between centre and periphery so perpetual that it eventually becomes a state - transgressivity, which "characterizes the forces continually acting upon heterogeneous spaces" (Westphal 2011: 46). These render the space "incessantly mobile" and "governed (so to speak) by an almost impalpable deterritorializing and evolutionary dialectic" (Westphal 2011: 52) ${ }^{5}$.

\footnotetext{
${ }^{5}$ Such a system evinces all the defining properties of what Deleuze and Guattari term a rhizome, namely the principles of connection, heterogeneity, multiplicity, signifying rupture, cartography and decalcomania. Although each rhizome contains lines of segmentarity according to which it is stratified and organised, there is a rupture in it whenever these explode to lines of flight and deterritorialisation. It may be broken but will always start up again either on its old or new lines (2000: 6-12).
} 
Drawing on Lefebvre, the third principle, referentiality, is based on the presupposition that the arrangement of words or tropes, though orderly and consistent, has no direct correspondence to the depicted reality. It is a construction, a discourse that establishes the space and, rather than reproducing the real referent, reproduces an experience of the real. However, as "human space only exists in the modes of this experience" (Westphal 2011: 85), these spaces of representation that constitute our lived space become vitally instrumental for our perception and interpretation of reality. The distinction between the real and the represented is thus blurred as the represented becomes part of the real, or even participates in its formation. Consequently, the fictional space enters a volatile relationship with the world of reference with a variable degree of mutual correlation.

These major principles of spatial-discursive heterogeneity are supplemented with other consequent phenomena, namely multifocalisation, the inviting of a multiplicity of views on a geographic referent without privileging any of them; polysensorality, the promoting of experiences in an environment coming from all the senses; stratigraphy, or highlighting the temporal variability of spaces which never unfold in pure simultaneity but in a permanently reactivating layering caused by the concatenation of diverse temporalities; and intertextuality, which refers to the architecture/architexture of space, that is the inherent interplay between spaces in texts and texts in spaces (Westphal 2011: 114-164, Tally 2011b: xiv-xv). The pivotal aspect of Westphal's geocriticism is its strictly geo-centred focus, which means that it takes the actual spaces/places at the centre of debate and draws on their textual representations in order to grasp them more thoroughly. In other words, it is a comparative mode of analysis aimed at "understanding a given place (through the problematics of representation) rather than studying a given set of representations (through the thematics of place)" (Prieto 2011: 21). What follows from this restricted scope is not only the absence of the ego-centred dimension that would be concerned with how the sense of a place affects those who encounter it, but also a recognition that it can only be used for textual representations of real-life territories.

A broader approach to geocriticism, though admittedly derived from Westphal's, has been developed by the American literary scholar Robert $\mathrm{T}$. Tally Jr. in so-called "literary cartography". It is a form of mapping narrative that takes into consideration both the social and psychological experience of space/place and the possibility of reflecting such spatial experience through a wholly imaginary literary environment. As he puts it, literary cartography is a "practice by which writers figuratively represent, or attempt to represent, the social space of the narrative or text, as well as the relationship of the individual or collective subject to a larger spatial, social, and cultural ensemble" (2016: 25). That is why it goes well beyond the reproduction of real-life referents towards imagined and mental spaces, thus accentuating the experiential and aesthetic dimensions of spatial representation and appropriation. His aim is to pay attention not only to places that writers and readers experience through texts, but also to the very nature of this experience and its impact on our views of ourselves. Such practice can thus "examine how the ways in which we are situated 
in space determine the nature and quality of our existence in the world" (Tally 2011a: 8).

From this understanding of geocriticism, it is just a step down to the phenomeno-logical conception that places emphasis on the interaction between the physical environment and the human psyche. This approach is subjectivist as it looks at places from within, giving "precedence to the density, complexity, and qualitative aspects of place experience", while the opposite, objectivist or scientific, approach "relies on the analytic abstraction and decentred perspective associated with maps" (Prieto 2012: 187). Eric Prieto, however, argues for a comprehensive theory of space that would reconcile these two visions by "bringing them together in a way that makes it possible to hold both perspectives in mind at the same time" (2012: 188).

Prieto tries to combine the two approaches in his geocritical analysis of fictional representations of space, seeking to find out how they form our attitudes toward the environment and how they imprint in the mental space of our consciousness. In accordance with the current, or postmodern, understanding of spaces as inherently heterogeneous and transitional, he emphasises the concept of the entre-deux or in-between place. It designates "the many different kinds of sites that fall between the established categories that shape our expectations of what a place should be and that often tend, therefore, to be misunderstood, maligned, or simply ignored" (2012: 1). The emergent, interstitial territories reflect and embody rapid and ongoing evolutionary changes - social, economic, demographic, cultural, political, technological, and environmental - of the globalised contemporary world, in that they themselves are situated in a process of transformation leading to new stages and possibilities. "These transformative processes have necessarily generated new modes of spatial organization, new kinds of habitats, and new ways of living together, some of which are destined to become an enduring part of the physical and cultural landscape even if they are not yet fully understood and accepted. In this sense, we could say that the entre-deux is a kind of master trope for our era" (Prieto 2012: 8-9) ${ }^{6}$. As it tends to be occupied with the productive potential of the peripheral, the liminal, the transitory and their often underappreciated properties, imaginative literature may become a crucial mediator in our understanding of lived spaces by complementing and enriching the perspectives of other disciplines.

In order to clearly define the object of a geocritical inquiry it is important to make a distinction between space and place. The first is a general notion, a broad concept that refers to any environment in which a person finds him/ herself. As such, it is rather loose and undetermined in terms of the individual's personal relation to it. Place, then, is a segment of space that is particularised and localised on the basis of an individual's more intense attachment formed through ascribing meanings, projecting ideas and making interpretations. Space is concretised into place by "being named" by the flows of power and negotiations of social relations

\footnotetext{
${ }^{6}$ This in-between place/space corresponds with what Deleuze and Guattari describe as a smooth space that is being striated, that is the smooth space which always possesses a greater power of deterritorialisation is attempted to be closed off, homogenised, yet which in the process of its striation develops other forces and emits new smooth spaces (2000: 474-500).
} 
of its occupants (Carter et al. 1993: xii). Therefore, place is "a setting to which individuals are emotionally and culturally attached" (Altman and Low 1992: 5), a section of space "enriched with human experience and understanding; an organized world of meaning" (Tuan 1997: 179). It is a highly complex field of interest, which is why an unequivocal definition of place is very difficult to formulate. One runs the risk of its being too indefinite.

Prieto suggests that it is "any geographical site [...] that is meaningful to someone, for whatever reason", and immediately mitigates this definition's vagueness by stressing its two principal features: first, it involves a human relation, we can speak of a place only when "a person comes along and enters into a meaning-generating relationship with it"; and second, it is an unstable relationship which may vary depending on the context of who thinks of a given site in terms of place and why and when they do (2012: 13). It follows that place has a much more immediate impact on our existence and identity than space and that it also represents a much more "formable" entity in that it can be unrestrictedly infused with new discursive meanings. In effect, these prove more influential for the place's significance than its actual physical and historical attributes $^{7}$. As some of these multiple discourses and projections are inevitably conflicting or even contradictory, each place becomes "subject to a dialogical struggle over the meaning of that site" (Prieto 2012: 14), and fiction can serve as an apposite and illustrative medium for this dialogic contestation.

Finally, the term "landscape" should be clarified in relation to the above established space-place dyad. It can be defined as a middle term between the indeterminate space and the more pinned down place since it "typically consists of several places, and yet it is linked to an area, a region, in a way space is not" (de Lange et al. 2008: xvi). Landscape is thus a greater geographical, but also more meaningful, unit than place, formed when a number of places interconnect as a result of a person's long-term habitation in, recurrent visits to or journeying through them. Endowed with meanings, places and landscapes are embedded with narratives, just as narratives allow us to comprehend and organise places. Reading and studying literary representations of places and landscapes, both real and imaginary, therefore enable us to think of them more thoroughly and systematically and be more attentive to the ways in which we perceive places in our inner universe. As Crace in his novel (re)presents wholly made up places/landscapes, many of which fall into the category of transitional or inbetween ones, Tally's and, in particular, Prieto's geocritical approach will be employed in the subsequent analysis.

\section{Continent}

Lowdo, the main protagonist of the first story, entitled "Talking Skull", is a university student of biology. Almost all his fellow-students are children of the

\footnotetext{
${ }^{7}$ In chapter "Barbarians at the Gates: Country House and the Poetics of the Imminent Decline", Tereza Topolovská, for instance, offers an in-depth analysis of the possible interaction and interference between a country house and its dwellers' mental world, their psychic, and physical in consequence, life with special focus on Sarah Waters' The Little Stranger.
} 
prominent townsmen, which is why he, as a country person, attracts much of their curious attention. When asked by his schoolmates' fathers about his ancestry and his family's apparent riches, he often resorts to vagueness and reticence. He is ashamed of the fact that the money which allows him to live a comfortable city life and be trained as a forward-looking natural scientist comes from his father's capitalising on superstition: selling the "milk" of freemartin cows for its supposed miraculous healing properties, especially its curing of infertility and impotence. The more Lowdo becomes accustomed with the modern industrial world and acquainted with biological knowledge, the more he is irritated by what he sees as his father's ignorant narrow-mindedness and obstinate irrationality. This is further intensified by the father's bullying tendency to mock his son by pointing out that while his "unenlightened" business has generated wealth and social status, Lowdo's studies have produced nothing but unproductive chatter.

Born and bred in the countryside, Lowdo is particularly associated by his fellow-students' fathers with the place and landscape where he grew up. In order to satisfy or at least fend off their inquisitiveness, he invents for them a neoArcadian image of rich land whose peacefulness and plenty are achieved thanks to methods of modern agriculture and labour management:

We sit and contrive between us answers which invent a wide flat valley, a leisurely shoulder-deep river, a contented village of a thousand compounds. Six thousand acres of fertile ground provide nourishment for plantations of black-bark tarbony, fields of maize and sunflower, herds of milk cattle. At the benevolent centre of this paradise, my conjured father, his accountant and estate manager discuss agricultural strategies. (Continent $\left.{ }^{8} 4\right)$

The reality, however, proves to be quite different. The village where his father lives is situated on the very edge of a flat valley, in its nearly barren backwater full of "odourless thickets of thorn and acacia" $(C 6)$, where there are no plantations, no road, no milk cattle, but "belted aurochs of the scrub-people" $(C 7)$ that are slow to mature and give beef. It is the part of the valley in which the prosperous landowners show no interest, where farmers are poor because their herds provide only modest amounts of food, rough skins, and dung for fuel and manure. The limited fertility of the soil and cattle makes the populace strongly value sexual potency, and their limited outlook and education make them turn to superstition and myth. The point of intersection of these two aspects of their daily existence is the source of Lowdo's father's earnings.

"Talking Skull" is a story about a person caught between the old and the new and the subsequent necessity for him to make an irreversible decision to keep up with the changing world. The freemartin farm itself is an in-between place - one that seeks to pander to primitive beliefs and irrational fears, yet which profits from strictly mercantile instincts of supply and demand - a peripheral, border territory whose latent, unacknowledged properties enable it to reflect such evolutionary transformations. This transgressive potential of the seemingly homogeneous and anachronistic homestead with hermaphrodite cows is clearly detectable in how Lowdo projects its future in his dreams. Following the

${ }^{8}$ Hereafter abbreviated as $C$. 
townsmen's advice that a profit-making superstition, no matter how ludicrous and outmoded, must be harnessed and turned to advantage rather than eradicated, he no longer envisions a corn and milk farm which he would run effectively thanks to his scientific knowledge. Instead, his dream contains the same freemartin "homelands far off in the scrub" ( $C$ 25), only run with a progressive system of management and logistics, extending the range of local customers to tourists and city dwellers. This imagined place is thus ultimately one of movement and transgression. It defies established spatial, temporal and social categories as it combines within itself contradictory forces and tendencies: deep-rooted, unvarying beliefs and the dynamism of modern trading methods, the circular seasonal temporal pattern and the forking timelines of investment planning, enclosed communality and trans-local financial flows.

"The World with One Eye Shut" is the most minimalistic of the stories in terms of spatial construction as it is reduced to one confined place - a prison cell. The story takes place in a country governed by an authoritarian military regime, which severely punishes even the smallest hints of opposition. This is also why the main protagonist, a young man without any ambition to undermine the establishment, becomes a political prisoner after he gets drunk in a pub and shouts a few offensive remarks about the soldiers who were making fun of him and his simple-minded sister. Accused of being part of an organised dissenting group, his hopes of being released are dashed as the interrogators do not believe in his innocence. The prison cell is far from being a dynamic in-between or heterogeneous place teeming with entropic energies and susceptible to transgression; on the contrary, it is a no-place intentionally conserved in its state. In fact, it evinces features of heterotopia as Michel Foucalt defines it: a countersite in which "all the other real sites that can be found within the culture are simultaneously represented, contested, and inverted. Places of this kind are outside of all places, even though it may be possible to indicate their location in reality" (1986: 24). Heterotopias contain a moment of exclusion as they "presuppose a system of opening and closing that both isolates them and makes them penetrable" (Foucault 1986: 26), and thus require a special act, gesture, ritual or procedure to get into them, and - in the case of a prison - also out of them.

Isolated from the town, not only does the cell stand outside other places, it also breaks from traditional temporality. It represents a kind of timelessness consisting of accumulated temporal mass layered cyclically through the individual inmates' fates and experience. The story's prison cell reflects the protagonist's previous life in that he was never free but always in a mental cell of paranoid fear of the regime's repressive measures, yet it also contests and inverts it in that he can say whatever he likes in there. His only chance of release seems to be the women protesting on a daily basis at the prison gate with photographs of their missing male relatives, particularly his mentally handicapped sister. The sad irony is that unlike the other women, his sister comes to stand at the gate because she has fallen for a soldier who works there as a guard. The only "landscape" his cell offers is what he can see from the small window with his face pressed close to the wall and one eye shut. This view is not only very limited, but also utterly monotonous since it only includes the barracks with the squads marching and exercising in the yard 
and the bustle of women searching and waiting for their men at the prison gate. In its narrowness and ironic distortedness, it is an ominous landscape of despair as it again and again reminds him of his impasse situation: the power of the system and the powerlessness and lack of interest of the outside world.

"Cross-country" is set in a remote mountain village that has recently been reached by the achievements of civilisation in the form of a newly established school where for each year a volunteer teacher from the developed world arrives to educate the local children. The latest newcomer, however, a Canadian named Eddy Rivette, differs from his predecessors by being a keen track runner who is not going to give up his everyday practice even in the hilly countryside where there are no suitable routes for long-distance running. He finds an adequately long, though arduous and uncomfortable, circuit from the school across the hills to the village store and back home. This route soon becomes his familiar physical, as well as mental, landscape, one of effort and strain but also joy and freedom, an experience "more noble and more worldly" (C 59) than competitive running:

Alone on the tracks worn by animals and borrowed by men, he encountered everything which he had expected: sunset, warm earth, a sense of liberation amongst a landscape and a people equally dispossessed. He picked his way, running all the time but choosing, heading for landmarks and favouring distance to the hard work of gradients. (C 52)

His regular evening running is thus the most gratifying part of the day, as he first experiences the beauty of the landscape and then a sense of connection with the villagers as the elders who gather at the local store watch him pass by and greet him with cheers. They have gradually become used to the teacher's peculiar activity, which they at first perceived as foolish and disturbing. Though it has not stopped Eddy from being seen as a quirky and embarrassing stranger, it has made him an enjoyable harmless attraction, someone to be tolerated and joked about rather than feared or detested.

However, the growing popularity of the teacher's running annoys 'Isra-kone, the most skilful member of the last pre-modern generation of boys who never attended schools and whose life-training consisted of traditional horsemanship and farming, as well as of a series of ancestral initiation rituals. The elders like him because he personifies all the age-old values and strengths they have respected their whole life, unlike the new ways of education and manners they look upon with mistrust and scorn. As a genuine highlander, 'Isra sees a rival in Eddy not only because the foreigner's eccentric daily workout attracts more attention than his horse riding skills, but also because he is making a claim to unity with the landscape which 'Isra considers exclusively his habitat. As the teacher becomes more acquainted with the terrain and his movement across the ridge becomes faster and more natural, the sight of him, paradoxically enough, evokes in the elders a somehow comforting prehistoric image of their species as he "seem[s] to tell them something about man and their mountain which they have never guessed - that men were like hares who could bounce across the black-studded basalt earth around which they had stumbled for centuries until the horse had come" (C 57). 
The race 'Isra challenges Eddy to is thus for him a vital duel for status and prestige, as well as for preserving his territorial ascendancy.

Eddy soon realises that running along the usual hilly path "amongst the slipping soils and half-chewed thorns" ( $C$ 59) would mean losing the race as 'Isra on his horse moves faster on these tracks. Eddy thus pragmatically opts for the longer, but more comfortable, and obstacle-free route through the flat floor of the valley, which allows him to speed up and be almost level with 'Isra when entering the home stretch leading to the store. The fact that the horse collapses just a few metres before the finishing line, too weary from labouring its way "amongst the treacherous descents" ( $C$ 65), and the teacher comes in first can thus easily be interpreted as a confirmation of resourceful modernity displacing cumbersome and inadaptable tradition. However, the story also implies that a significant role in this process will be played by a radical revision of the community's current sociospatial arrangements and, consequently, a redefinition of the dwellers' territorial identity. What they see as an organic bond with their homeland would inevitably undergo a transformation no matter who races: the loser turning into a local antique folk curiosity, the winner back home "in Montreal with his colour slides and a life-long commitment to this seventh and shabby continent" ( $C$ 58), cherishing nostalgic memories of a lost world.

"On Heat" opens with the narrator's childhood recollection of how, together with her two younger sisters, she assisted her father, a professor of biology, with photographing and measuring the mating tiger crabs on a beach at the summer solstice. The memory itself is based on a family photograph published on the back cover of the father's monograph with the background of a beautiful seascape and tranquil, empty beach swarming with the coupling crustaceans. Yet the narration soon reveals that this idyllic image of an esteemed professor's life and work is a kind of redemption for the more obscure moments of the family's history. Long before taking an interest in tiger crabs, the young natural scientist's object of interest was anthropological - a rare primitive community living in a tropical forest. Accompanied by his newlywed wife, he sets out to research the tribe's peculiar animal-like reproductive habits and rituals consisting of synchronous conception and communal parturition. However, ending up at odds with the tribe, who showed no willingness to be subjected to the professor's measurements and experiments, the expedition returns home empty-handed, save for Puppy, a thirteen- year-old native girl who expressed her wish to be taken away to their world.

Prompted by the few photographs, the narrator, now aged seventy, is trying to compose a comprehensive image of her parents' life prior to her birth, but her only sources of information are her semi-deranged and forgetful mother and her late father's diary notes. She learns from her mother that her father secretly carried on observations, samplings and computations of Puppy's menstrual and ovarian cycles, and that he included his wife in the experiment sample to see if the two women's reproductive systems would synchronise or not. However, the mother, fed up with being an object of her husband's unrelenting scientific scrutiny, and his consequent avid libido, sabotages his research and spoils the results of the measuring, thus making Puppy the only object of the father's examination. Yet 
only when the narrator consults in detail her father's measurement notes and pays better heed to the differences between her and her mother's and sisters' physiognomies does she realise, to her dismay, that her real mother was Puppy. The narrator's central memory of the seaside where she spent so many happy moments recurs in the process of her gathering and composing bits and pieces of the unknown and evasive past as a firm landmark, a certainty. Yet this is only until she understands that the true point of reference in her life story occurred long before this. Her father's scientific interest in animals' reproductive behaviour was expressed out of necessity, very likely as a means of escape from his personal and professional failure when carrying out research on a human being. The soothing imaginary landscape of her childhood memory thus turns out to be illusory and collapses. It is disturbed by intrusive images, particularly that of the closing of the door of her father's study in which he was to embark on the fateful examination of the "kidnapped maid" (C 90).

The narrator of "Sins and Virtues" is "the last and certainly the most distinguished of calligraphers in the old Siddilic script" (C 103). Being an old man with arthritic hands no longer capable of firmly drawing letters and characters, his only ambition is to live peacefully off his savings, spending his days having simple meals and doing three shifts at his desk out of habit, yet producing nothing but worthless doodles. He is in fact getting ready for the very last script of his life - his Sins and Virtues list that will be buried with him when his time comes. As no one else can practise such calligraphy any more, his works since his retirement have become scarce and valuable art; rich people from America and Europe buy them up for galleries and private collections. Consequently, many forgeries of his works appear to satisfy the increasing demand. Only at this moment does the government realise that they are losing profit by letting foreigners take the artefacts from the country and decide to prohibit the trade. However, it is too late as most of the narrator's works have already been sold. The Minister himself pays a visit to his house and urges him, on the promise of money, to produce ornamental canvases decorated in the ancient script for a travelling exhibition with an auction. Trapped in a commission he cannot fulfil, the narrator continues his unproductive daily routines, listlessly waiting for what his fate brings him.

He was born and grew up in the country but made his career and name in the city, and both these places still play a determining role in his life. The first is a small village, which he visits once a year on his birthday. As the custom used to be to plant an acacia tree when a son was born, he always goes to see "his" tree and also shows reverence to those of his ancestors. The birthplace is thus for him reduced to the acacia grove at the edge of the village where he goes to meditate, perform a few private rituals and pray for a tolerable demise. It is a peripheral place even in the context of the distant village, a relic the villagers respect out of superstition rather than tradition, waiting patiently till the last surviving contemporary dies and the trees will be withered enough to be cut down for firewood. Yet for the narrator, it is also a present reminder of his imminent ending. The latter is represented especially by the marketplace where he used to have his calligrapher's booth and where he spent the best 
parts of his professional career, when almost all public places were decorated by his hand. Yet this market is also a cityscape of his mind that no longer exists - the dilapidated booths are no longer in use, replaced by modern airconditioned stores with fake shop fronts as the owners have sold the original ones to Americans, and the narrator in fact no longer goes there and sends his apprentice instead.

It is only when the situation becomes truly desperate that the narrator starts taking evening walks to the former marketplace, enjoying the status of a local celebrity and the reminder of his former fame and reputation, ending his strolls in the Syrian bar with a cup of tea and a chat with the owner. After one such conversation, the narrator has the brainwave to pass off to the Minister as his own work the Syrian's collection of forged canvasses, regardless of their numerous errors. Not only does he pretend to have authored the second-rate fakes, he even adds to them his own Sins and Virtues parchment. By doing this, he saves the peace and comfort of his remaining days, but at the cost of losing his professional honour and moral credit, violating the customary maxim that "the sin-lister must be free from sins" ( $C$ 101). However, this resignation of his principles does not bring him contentment. Instead it pollutes his mind and he loses all interest in life, which is reflected in the consoling landscape that dominates his imagination. It is no longer the bustling marketplace or a fashionable Western gallery, but the tranquil acacia resting place where his ashes will be taken: "a forest of trees, almost bare and leafless, with the moon hovering over the horizon. Is it dawn or dusk? Soon we all shall know" (C 123).

"Electricity" tells the story of how a small, backwater town gets electrified. Awni, the pathetic warden of the local restaurant called the Rest House, naively believes that this achievement is the result of his countless petitions to the Minister. In fact, the true reason is that the Minister's personal secretary intends to cheaply purchase a piece of land there and build on it a small gourd farm with a comfortable lodge. Awni dismisses the schoolteacher's warnings that electricity can become addictive and easily enslave rather than serve those who do not use it wisely. Instead, he orders all imaginable electrical equipment, including a monumental ceiling fan with huge propellers, which is to be switched on as a gesture of thanks and tribute to the Minister who will pay a personal visit to the opening ceremony. The deluded Awni cherishes the idea that with electricity the town will quickly turn into a modern city with his Rest House as its progressive centre, an emergent place symbolising the town's transitional evolutionary changes. However, following Awni's fawning speech to the pompous Minister, the oversized fan's fiercely spinning propellers damage the building, hurting many of the assembled people, including the Minister on whom the fan eventually falls.

The motif of the townscape plays a key role in the story: it is somnolently still, with bad and dusty roads connecting the small gourd farms with hand pumps and the administrative buildings. It is lit by oil lamps at night and people enjoy communal life on the veranda of the Rest House. The majority of the townspeople like their place as it is, being rather suspicious and superstitiously fearful of change. They watch the electricians erecting pylons 
and laying cables with aloof curiosity rather than eagerness and expectation. An exception is Awni who already pictures a radically transformed town with new roads, an airstrip, a cinema, a factory and an abattoir ( $C$ 139). The Minister's Secretary, however, has no interest in what he sees as a one-horse town, and as he is driving towards his planned estate, he is already transforming in his mind the serene and semi-wild landscape into one that generates profit:

He has seen maned deer, quibbling flocks of ground-thrush, a mesmerized bandicoot caught mid carriageway by the engine roar. [...] All good pot animals, and sitting targets, too. The thought of land here becomes more attractive. The comfortable family lodge with a small gourd farm transforms into a hotel for hunters, weekend marksmen keen on game but untempted by treks and danger and patience. (C 141)

The businesslike Secretary goes on scheming to select "a good site, close to the road and the police station, but wind and neighbour free" ( $C$ 142), a strip of land ready to be exploited and commercialised to the fullest capacity, regardless of the rest of the place. Sadly for Awni, the resulting reality is formed in the Secretary's image: the only modernised part of the town is that adjacent to the Secretary's property. The damaged Rest House is closed and avoided by the locals as a site of bad omens, and the luxurious Huntsman Hotel with its garden bar, pool, patio restaurant, cane settees and glass-topped tables ( $C$ 150) stands out in the townscape as a bitter reminder of the warden's foolish ambition.

In the last story, "The Prospect from the Silver Hill", a mining company agent is sent to the mountains in the vanguard of a government project to exploit the country's potential mineral resources. Posted in a cabin at a hill called Ibela-hoy, his task is to inspect the soil and rocks for signs of precious metals and send samples and reports to the company. Wishing for a family but having none, he leads a solitary and joyless life and suffers from chronic insomnia. The deprived agent gradually develops severe depression combined with exhaustion from lack of sleep. The main symptoms of his disturbed psyche are vivid daydreams and frenetic soliloquies, and he eventually reaches a state of psychotic deliriousness. The more futile his attempts to get some sleep and the greater his desperation become, the more attached he grows to the landscape around him. He takes long walks along the cliffs and rocks, collecting pebbles and stones for his sheer pleasure in their shape and colour rather than for geological inspection. Dreaming of a wife and two children, he at first entreats the boulders to materialise this imaginary projection for him, but later he embraces and kisses them as if they were his family. Having nothing and no one to lean on, the stones and pebbles become for him the whole of his world, the miniaturised and condensed space of his imagination, evoked by his hopes and memories:

He was struck how - held and turned in the daylight - each stone was a landscape. Here was a planet, a globe, with the continents grey and peninsular, the seas cold and smooth to the touch. And here a coastline, one face the beach, four faces cliff, and a rivulet of green where the children and donkeys could make their descent. And here $[\ldots]$ were the muddied banks of rivers and the barks of trees modelled and 
reduced in deep, toffee earth. [...] He remembered how, when he was a child, they had buried his father. The grave was open when the body came. They were clays and flints piled on the yellow grass. (C 157-158)

Realising that the barren, rocky area offers him a hideaway from the failures and pressures of his previous life, he makes up his mind to protect it from any kind of intrusion. Having dug the stones back into the earth and hidden minerals and gemstones in places in the valley where they would be impossible for others to find, he deliberately sends the company samples of worthless clay and sandstone.

However, his strategy is jeopardised when the survey team find pebbles with fragments of silver on the valley bluffs and ask him for an expert confirmation of the rare metal's presence. Knowing that the metallic veins in the pebbles are really silver, he immediately envisions the imminent uncompromising transformation of the secluded landscape, and of his own place in it:

Once the word Silver was spoken in the company offices, Ibela-hoy could count on chaos; there would be mining engineers, labour camps, a village, roads, bars, drinks, soldiers. Bulldozers would push back the soil and roots of silver would be grubbed like truffles from the earth. Dynamite, spoil heaps, scars. And he, the company agent, the man who spilled the beans, would have no time to reconcile the stones, the dreams, the family, the fatigue, the sleeplessness which now had reached its final stage. (C 163)

Intimidated by such a prospect and the noises of the company jeeps sent to drive him away from the station, he decides to take the found silver pebbles and climb up to the ultimate "location of his dream" ( $C$ 164) - the sun-lit summit of the highest rock where he and his wife and children would lead a primitive life like prehistoric people, "where the rocks were hot and moving, where quakes and volcanoes turned shales to schists, granite to gneiss, limestone to marble, sandstone to quartz, where continents sank and rose like kelp on the tide" ( $C$ 165). Having reached the sought-for landscape, he at first hides the silver in the snow and then gives himself over to the safety of his familial daydreaming until a helicopter or death takes him away.

\section{Conclusion}

Although the individual stories feature different characters in different life situations, they are linked thematically in that they all deal with communities in the process of socio-historical transitions as represented in the fates of individuals. They dramatise various forms of the conflict between rural and urban, outdated and modern, customary and pragmatic, intuitive and rational. The strength of the novel lies in its refusal to present the two evolutionary stages as binary opposites - one good and beneficial, the other devalued and detrimental. Instead, they are seen as two concurrent drives whose seemingly countervailing lines of force in fact show a strong tendency to appropriate and complement, rather than cancel out or annihilate each other. In order to achieve this thematic narrative coherence, 
Crace makes use of several devices in order to render and contemplate the manifest discord between the persisting, or surviving, and the upcoming, or superseding. Prominent among them are recurrent motifs and symbols and, crucially, the multi-layered portrayal of diverse geographic locations.

Due to the diversity of the presented landscapes, Continent allows a complex geocritical analysis, especially with regard to the principles of spatiotemporality and transgressivity. Most of its stories rest on the same principle: a homogeneous - orderly, steady and self-sustained - place/space gets heterogenised by the forces of modernity into a place/space of transition, transgression and disorder. The place shifts from a stable and clearly demarcated spatial organisation to an entropic deterritorialisation. These traditional socio-spatial units, such as the remote villages in "Talking Skull" and "Cross-country", the market town in "Sins and Virtues", and the provincial townlet in "Electricity", are governed by regular temporality consisting of the consecutive events and routines of the natural cycle of the year. This is violated by the stern dynamic of the lines of progress that strive to invert these cycles or level them off. As the regular temporal cyclicality breaks down into disparate points and isotropic timelines, the socio-spatial structure begins to collapse, generating energies that propel the system to a new evolutionary stage. The progressive impacts distort and uproot the former rules and values and, at the same time, subject the destabilised milieu to other homogenising tendencies by imposing on it its own regulations and limits.

However, these are by no means accepted unconditionally, but are rather defied and transgressed by resistant impulses, social as well as spatial. The outcomes of the activities of these colliding forces are in-between, liminal places in a state of dialogical struggle to maintain their meaning and identity in the face of large turbulent changes. Crace shows how the overlooked and underrated productive potential of such places empowers them to fight back and have a substantial say in the resulting form of emergent modes of socio-spatial arrangement, be it the reconciliation of pragmatic business with superstition in the modernised freemartin farm, the mountain village tentatively opening its landscape to modern leisure-time activities, or the bizarre cohabitation of a backward town and a posh, high-end hotel. Although these places cannot resist modernity absolutely, they still manage to retain their interstitial, border character.

The novel also explores various ways of experiencing place/space, the interaction of the physical environment and the protagonists' psyches. The running teacher's mountain trail of joy and liberation, the biology professor's daughter's nostalgic childhood snapshot image of the tiger crab beach, the elderly calligrapher's memory of the bustling marketplace, or the company agent's daydreamed family among the rocks and boulders are all examples of mental and imaginary landscapes that the characters conceive in order to come to terms with the places and with themselves. However, Crace never lets readers immerse themselves in these made-up landscapes for long; instead, he always confronts them with rather exact descriptions of the actual environment, combining minute details and aesthetic evocation. His prose thus achieves precisely the effect of reconciling the objectivist and the abstract with the experiential and phenomenological, which Eric Prieto calls for in his geocritical inquiry. 
The diverse environments of the individual stories - the villages, the town, the city with the marketplace and the prison, the beach, the valley and the mountains - compose representations of an imaginary realm, a big country or a continent, at the dawn of a technological and mercantile modernity whose rapidity and instantaneousness often clashes with the deep-rooted customs and prejudices of the slow-paced old world. Rather than forming a consistent, comprehensive narrative they add up to a jigsaw puzzle, a topographic patchwork of disparate, though related, pieces. Continent thus represents a specific example of literary cartography, a mapping narrative that, through a collection of fragmentary spatial images, achieves a complex landscape with an exceptional unity of geographic, aesthetic, symbolic, experiential and mental dimensions. This intrinsic richness of the rendered territories makes them an integral part of the novel's narrative framework as they prove crucial on the level of character construction and thematic composition.

\section{References}

Altman E, Low SM (1992) Place Attachment. New York: Springer.

Begley A (2002) A Pilgrim in Craceland. Southwest Review 87(2 \& 3). Retrieved from: https://bit.ly/2HU4wtX. [Accessed: 29 November 2017]

Begley, A., 2003. Jim Crace, The Art of Fiction No. 179. The Paris Review, 167. Retrieved from: https://bit.ly/2MB5heT. [Accessed: 29 November 2017]

Bookgroup.info (2007) Jim Crace: interview. Retrieved from: https://bit.ly/2MyQ1Ok. [Accessed November 29, 2017].

Carter E, Donald J, Squires J (1993) Introduction. In EJ Carter, J Donald, J Squires (Eds.), Space and Place: Theories of Identity and Location (pp. vii-xv). London: Lawrence and Wishart.

Coverley M (2006) Psychogeography. Harpenden: Pocket Essentials.

Crace, J. (2008 [1986]). Continent. London: Picador.

de Lange A, Fincham G, Hawthorn J, Lothe J (2008) Introduction. In A de Lange, G Fincham, J Hawthorn, J Lothe (Eds.), Literary Landscapes: From Modernism to Postcolonialism (pp. xi-xxv). Basingstoke: Palgrave Macmillan.

Deleuze G, Guattari F (2000). A Thousand Plateaus: Capitalism and Schizophrenia. Translated by B Massumi. Minneapolis: University of Minnesota Press.

Foucault M (1986) Of Other Spaces. Translated by J Miskowiec. Diacritics 16: 22-27.

Garrard G (2011) Ecocriticism. Oxon: Routledge.

Hashas M (2017) Intercultural Geopoetics in Kenneth White's Open World. Newcastle upon Tyne: Cambridge Scholars Publishing.

Kermode F (April 12, 1998) Into the Wilderness: Review of Quarantine. The New York Times Retrieved from: https://nyti.ms/2teBZKn. [Accessed: 29 November 2017]

Lawless A (n.d.) The Poet of Prose - Jim Crace in interview. Three Monkeys Online. Retrieved from: https://bit.ly/2HWjlfx. [Accessed: 29 November 2017]

Mathews P (2012) Review: Continent (1986) by Jim Crace. English Literature Today. Retrieved from: https://bit.ly/2JOEQo8. [Accessed: 15 December 2017]

Peraldo E (2016) Introduction. The Meeting of Two Practices of Space: Literature and Geography. In E Peraldo (Eds.), Literature and Geography: The Writing of Space throughout History (pp. 1-16). Newcastle upon Tyne: Cambridge Scholars Publishing. 
Prieto E (2011) Geocriticism, Geopoetics, Geophilosophy, and Beyond. In RT Tally, Jr. (Eds.), Geocritical Explorations: Space, Place, and Mapping in Literary and Cultural Studies (pp. 13-27). Basingstoke: Palgrave Macmillan.

Prieto E (2012) Literature, Geography and the Postmodern Poetics of Place. Basingstoke: Palgrave Macmillan.

Sinclair I (2003) Lights Out for the Territory. London: Penguin Books.

Tally RT Jr. (2011a) On Geocriticism. In RT Tally, Jr. (Eds.), Geocritical Explorations: Space, Place, and Mapping in Literary and Cultural Studies (pp. 1-9). Basingstoke: Palgrave Macmillan.

Tally RT Jr. (2011b). Translator's Preface: The Timely Emergence of Geocriticism. In B Westphal (Eds.), Geocriticism: Real and Fictional Spaces (pp. ix-xiii). Basingstoke: Palgrave Macmillan.

Tally RT Jr. (2016) Adventures in Literary Cartography: Explorations, Representations, Projections. In E Peraldo (Eds.), Literature and Geography: The Writing of Space throughout History (pp. 20-36). Newcastle upon Tyne: Cambridge Scholars Publishing.

Tew P (2006) Jim Crace. Manchester: Manchester University Press.

Tuan Y (1997) Space and Place: The Perspective of Experience. Minneapolis: University of Minnesota Press.

Westphal B (2011) Geocriticism: Real and Fictional Spaces. Translated by RT Tally Jr. Basingstoke: Palgrave Macmillan.

White K (1992) Elements of Geopoetics. Edinburgh Review 88: 163-178. 
